\title{
THE DEVELOPMENT OF SUPPORTING TOOL APPLICATION SOFTWARE FOR PROCESSING STATISTICAL DATA BASED ON VISUAL BASIC APPLICATION (VBA)
}

\section{PENGEMBANGAN SOFTWARE APLIKASI ALAT BANTU OLAH DATA STATISTIK BERBASIS VISUAL BASIC APLICATION (VBA)}

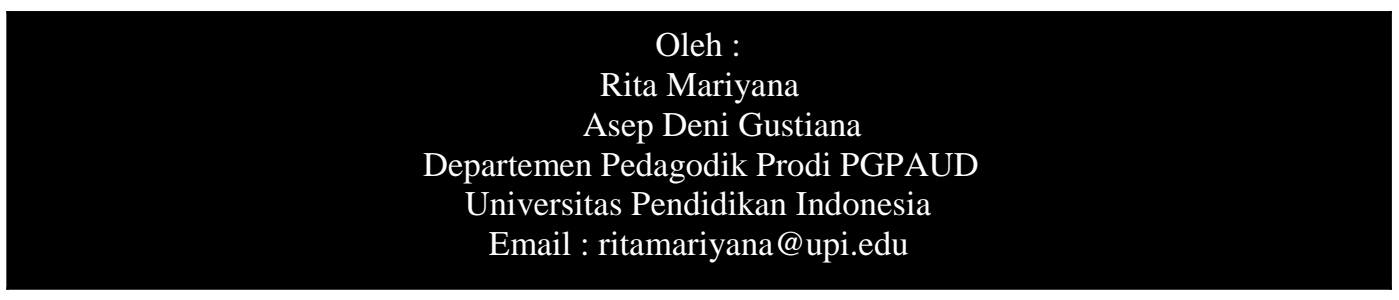

Abstract. This study aims to develop to improve the quality of learning by making statistical data processing tools are easy to understand, easy to use by following the flow and statistical methods so that students can quickly perform data processing in both subjects for task completion and the completion of an essay, a thesis or a dissertation. To describe the results of a study to improve the quality of learning with this statistical tool research uses descriptive method, the purposive sampling technique to students taking statistics courses in early childhood teacher education study program Indonesia University of Education. Data from the study, questionnaires, interviews, observation and documentary studies analyzed by quantitative and qualitative techniques. The final product of this study is to improve the quality of products tools of statistical data processing and statistical are quickly understood and easily used not only for Early Childhood Education students but for students taking a statistics course.

Keywords : :Tools, Learning Media, Process, Statistics

Abstrak. Penelitian ini bertujuan melakukan pengembangan untuk meningkatkan mutu pembelajaran dengan membuat alat bantu olahdata Statistik yang mudah dipahami, mudah digunakan dengan mengikuti alur dan metode Statistik sehingga mahasiswa dapat dengan cepat dan mudah dalam melakukan pengolahan data baik itu untuk penyelesaian tugas mata kuliah maupun penyelesaian skripsi, tesis, ataupun disertasi. Untuk mendeskripsikan hasil penelitian dari peningkatan mutu pembelajaran dengan alat bantu Statistik ini penelitian menggunakan metode quasi eksperimen, dengan teknik purposive sampling pada mahasiswa yang mengikuti mata kuliah Statistik pada Program Studi Pendidikan Guru Pendidikan Anak Usia Dini Fakultas Ilmu Pendidikan Universitas Pendidikan Indonesia. Produk akhir penelitian peningkatan mutu pembelajaran ini adalah produk aplikasi alat bantu olahdata Statistik untuk mata kuliah statistik yang cepat dipahami dan mudah digunakan untuk semua mahasiswa yang mengambil mata kuliah Statistik serta untuk pengolahan data penelitian.

Kata Kunci : Alat Bantu, Olahdata, Statistik

\section{A. PENDAHULUAN}

Perkembangan dan kemajuan dunia pendidikan sangat dipengaruhi oleh perkembangan ilmu pengetahuan dan teknologi. Munculnya berbagai macam produk teknologi, dapat dimanfaatkan dan dipergunakan dalam bidang pendidikan, serta memberikan kesempatan kepada para pendidik dan tenaga kependidikan untuk meningkatkan kualitas pendidikan melalui peningkatan proses belajar mengajar.

Komputer sebagai salah satu media pembelajaran dengan perangkat lunak (software) yang diprogramkan dengan baik 
sesuai dengan prinsip pembelajaran, merupakan sarana yang tepat untuk membantu guru dalam proses belajarmengajar. Sebagaimana dikemukakan oleh Nana Sudjana dan Ahmad Riva'I : "Materi pelajaran, umpan balik, ilustrasi, ringkasan, dan pertanyaan dikemas ke dalam suatu paket program pembelajaran, sehingga dapat menciptakan interaksi edukatif antara siswa dengan paket pembelajaran tersebut secara individual"

Belajar adalah suatu proses yang kompleks yang terjadi pada semua orang dan berlangsung seumur hidup. Adanya perubahan tingkah laku dalam diri pembelajar merupakan salah satu tanda seseorang telah melakukan proses belajar pada dirinya, baik perubahan yang bersifat pengetahuan (kognitif) dan keterampilan (psikomotor) ataupun yang berkaitan dengan nilai dan sikap (afektif).

Proses pembelajaran yang efektif harus dimulai dari pengalaman langsung/kongkrit dan kemudian menuju kepada pengalaman yang lebih abstrak. Informasi verbal cenderung akan membosankan. Dengan adanya media, pesan-pesan pelajaran yang bersifat abstrak dapat divisualisasikan, sehingga siswa merasa tertarik terhadap apa yang dipelajarinya. Rasa ketertarikan ini akan berdampak pada tumbuhnya motivasi yang secara langsung akan meningkatkan hasil belajar siswa. Program pembelajaran berbasis komputer menawarkan program pembelajaran yang dinamis yang diasumsikan lebih baik. Dengan paket pembelajaran berbasis komputer model tutorial yang dikemas dengan baik diharapkan dapat menghasilkan proses belajar-mengajar yang lebih baik dengan indikator hasil belajar siswa yang meningkat.

Dalam penelitian ini penggunaan media ajar berbentuk aplikasi komputer dimanfaatkan untuk menjelaskan materi kuliah statistik yang dikemas dalam sebuah aplikasi alat bantu pengolahan data statistik berbasis VBA .

Berkaitan dengan hal di atas, maka permasalahan umum dalam penelitian ini dirumuskan sebagai berikut : "Bagaimanakah pengaruh aplikasi alat bantu pengolahan data statistik berbasis VBA untuk meningkatkan hasil belajar mata kuliah statistik".

Untuk mengukur perbedaan pengaruh media ajar aplikasi alat bantu pengolahan data statistik berbasis VBA adalah dengan membandingkan skor hasil belajar mahasiswa yang menggunakan program aplikasi alat bantu pengolahan data statistik berbasis VBA antara sebelum diberi perlakuan dengan sesudah diberi perlakuan.

Secara umum penelitian ini bertujuan untuk mengetahui pengaruh 
aplikasi alat bantu statistik terhadap peningkatan hasil belajar mahasiswa pada mata kuliah Statistik di Prodi PGPAUD FIP UPI.

Metode yang digunakan dalam penelitian ini adalah metode kuasi

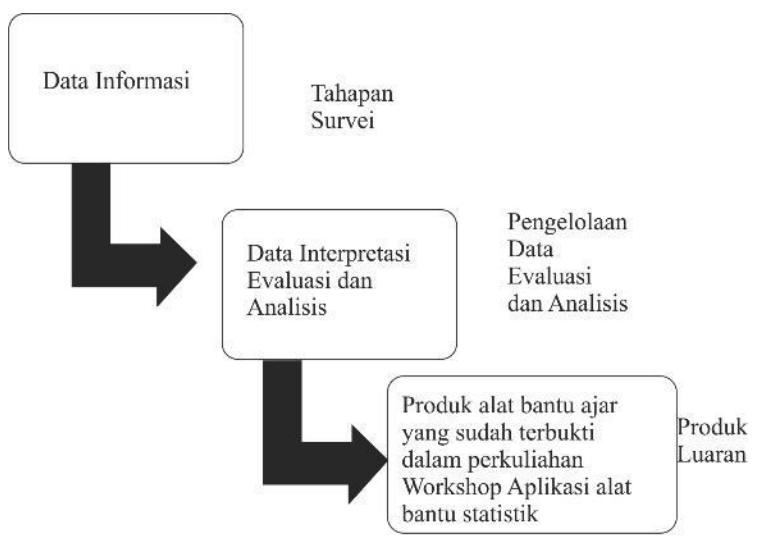

Gambar 1. Prosedur Penelitian
Penelitian
dilakukan
pada
program media pembelajaran berbasis
Mahasiswa, yaitu kelompok
eksperimen yang menggunakan
komputer (branching) dan tipe lurus
aplikasi alat bantu statistik dan
Tabel. 1
Perlakuan Pada Tiap Variabel Penelitian
(linear).

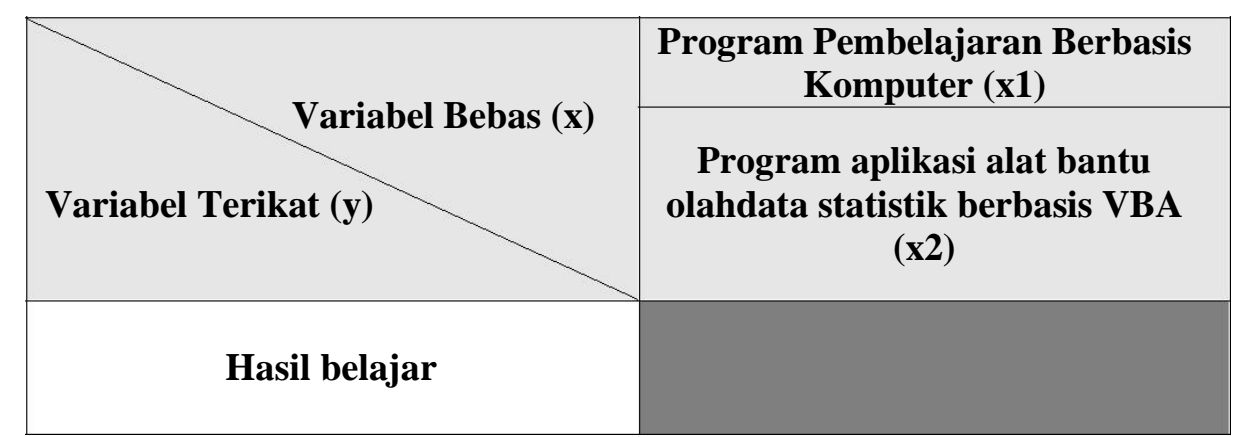

\section{Desain Penelitian}

Adapun desain yang digunakan

dalam penelitian ini adalah desain pre-tes pos-tes menggunakan eksperimen, yang salah satu ciri utama metode ini adalah tidak dilakukan penugasan random, melainkan menggunakan kelompok subjek yang telah ada.

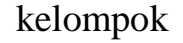

eksperimen

tanpa

penugasan random. Desain penelitian

dapat dilihat pada gambar 2 .
$O_{1}$
$\mathbf{X}$
$O_{3}$ 


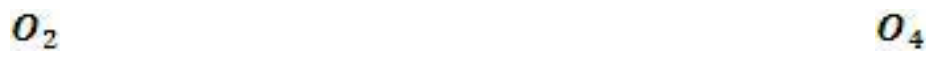

Gambar 2.

Nonequivalent Control Groups Desaign (Sugiyono, 2008: 79)

Keterangan :

$O_{1}:$ pretes kelas eksperimen

$\mathrm{O}_{2}$ : pretes kelas kontrol

$\mathrm{O}_{3}:$ postes kelas eksperimen

$\mathrm{O}_{4}$ : postes kelas kontrol

$\mathrm{X}$ : Aplikasi statistik berbasis VBA

Dalam desain penelitian ini, subjek penelitian diambil dalam bentuk kelompok kelas tanpa melakukan penugasan random. Tidak dilakukannya penugasan random ini disebabkan peneliti tidak mungkin mengubah kelas yang telah ada sebelumnya, untuk menentukan subjek penelitian ke dalam kelompokkelompok eksperimen. Kemudian atas pertimbangan bahwa kelompok dalam suatu kelas biasanya sudah mapan, maka apabila peneliti membentuk kelompok baru dikhawatirkan akan mengakibatkan rusaknya suasana kealamiahan kelas tersebut. Atas dasar pertimbangan inilah peneliti menggunakan kelompok kelas yang telah ada dan melakukan eksperimen terhadap kelompok-kelompok tersebut dengan metode kuasi eksperimen.

\section{Manfaat Penelitian}

Adapun manfaat penelitian yang diharapkan adalah sebagai berikut:

a. Bagi Disiplin Ilmu Teknologi Pendidikan

Penelitian ini diharapkan dapat menjadi bahan dan alat bantu media pembelajaran khususnya mata kuliah statistik. Aplikasi alat bantu statistik ini dapat menjadi solusi khususnya untuk mengolah data statistik bidang teknologi pendidikan, terutama dalam memaksimalkan penggunaan fasilitas komputer di laboratirium komputer PG PAUD.

b. Dosen dan Tenaga Kependidikan

Sebagai bahan informasi bagi tenaga kependidikan serta pihakpihak yang memberikan perhatian terhadap pelaksanaan dan pengembangan program pembelajaran yang menggunakan komputer untuk membantu pelaksanaan proses belajarmengajar di setiap jenjang lembaga pendidikan.

c. Bagi Mahasiswa

Hasil penelitian penggunaan aplikasi alat bantu statisik dan program media pembelajaran 
berbasis komputer model branching dan linier tutorial ini diharapkan dapat digunakan untuk menyelesaikan masalah statistik dalam pendidikan dan membantu pengolahan data stastisik untuk skripsi.

d. Bagi Peneliti Lainnya

Bagi peneliti lainnya yang berminat untuk mengkaji mengenai penggunaan aplikasi alat bantu statistik dan media pembelajaran. Hasil penelitian ini dapat dijadikan sebagai bahan masukan dan studi pendahuluan untuk memahami penggunaan komputer dalam pembuatan media pembelajaran dengan variabel yang berbeda dan permasalahan yang lebih banyak.

e. Bagi umum

Produk yang dihasilkan berupa alat bantu pengolah data stastistik dapat digunakan untuk masyarakat yang lebih luas tidak hanya untuk membantu olahdata statistik untuk bidang pendidikan saja tapi dapat digunakan untuk bidang lainnya yang lebih luas.

Subjek dalam penelitian ini adalah mahasiswa yang mengambil mata kuliah statistik di PGPAUD FIP UPI Bandung. Populasi penelitian ini adalah mahasiswa yang mengambil mata kuliah statistik di PGPAUD FIP UPI Bandung. Teknik random sampling merupakan teknik sampling yang dilakukan dengan memberikan peluang atau kesempatan kepada seluruh anggota populasi untuk menjadi sampel. Dengan demikian sampel yang diperoleh diharapkan merupakan sampel yang representatif.

Desain Sistem Flowchart Aplikasi

Berikut ini adalah diagram desain sistem alat bantu statistik VBA Excel yang telah dikembangkan:

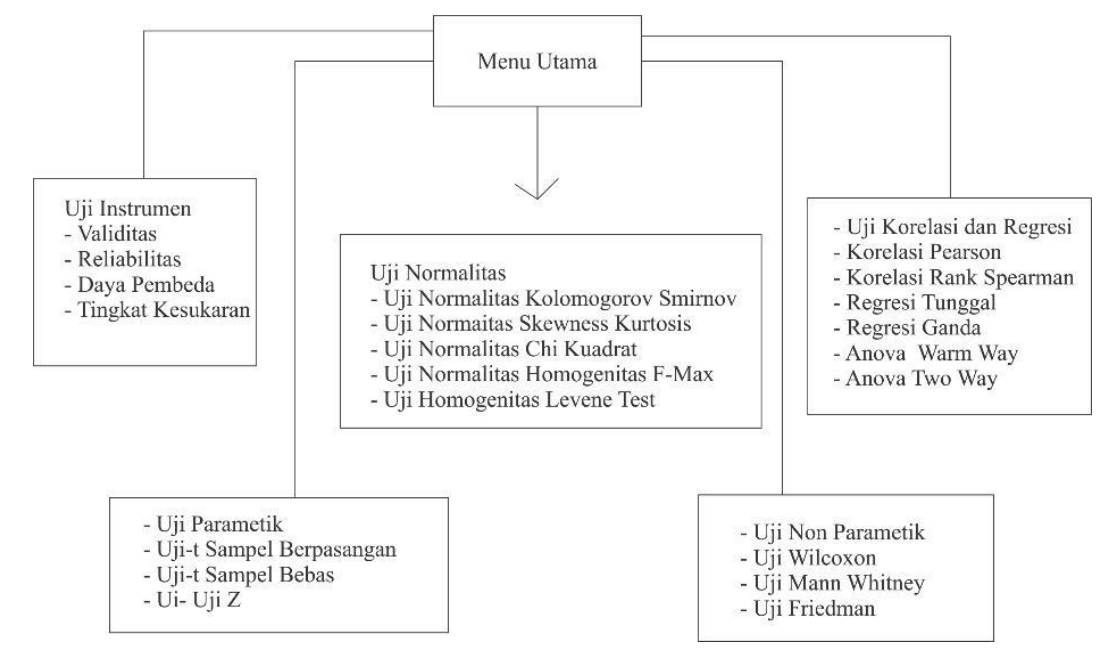

Gambar 3. Desain Sistem Flowchart Aplikasi 
Gambar diatas menampilkan alur diagram alur aplikasi alat bantu olahdata statistik berbasis VBA Excel. Dimulai dari Uji Instrumen, uji normalitas, uji korelasi, regresi dan uji perbedaan rata-rata baik untuk parametrik maupun non parametrik.

\section{Evaluasi dan Implementasi}

a. Evaluasi

\section{1) Subjek Uji Coba}

Sebagai suatu kegiatan penelitian pengembangan media pembelajaran, produk harus melalui tahap uji coba terlebih dahulu. Pengujian dimaksudkan untuk mendapatkan data yang dapat digunakan untuk menetapkan kualitas dari produk yang dihasilkan. Proses uji coba dilakukan melalui dua proses, yaitu uji ahli, dan uji kelompok.

\section{2) Uji Coba Ahli}

Uji coba ahli dilakukan oleh ahli pengolahan data penelitian. Tahap ini berguna untuk evaluasi hasil pengolahan data apakah sesuai atau berbeda dengan hasil yang seharusnya. Aplikasi diuji apakah ada atau tidaknya penyimpangan logika.

\section{3) Uji Coba Kelompok}

Ujicoba kelompok dilakukan terhadap mahasiswa PGPAUD yang mengambil mata kuliah Statistik. Prosedur ini berguna untuk melakukan penilaian apakah aplikasi alat bantu statistik berbasis VBA Excel yang dibangun dapat berjalan baik untuk menghitung hasil penelitian.

4) Pengujian Instrumen Pengujian instrumen dalam penelitian pengembangan alat bantu olahdata statistik berbasis VBA excel menggunakan instrumen angket Skala Likert dengan empat pilihan. Penelaahan instrumen pengujian dilakukan oleh pakar penelitian. .

5) Analisis Hasil Pengujian Analisis data terhadap hasil yang diperoleh bertujuan untuk mengetahui respon terhadap pengembangan alat bantu olahdata statisik berbasi VBA Excel yang telah dibuat. Angket yang diperoleh kemudian dianalisa menggunakan pendekatan analisis item summated scales dari Skala Likert (Kothari,2004:83 ), dimana skor akhir didapat dengan menggunakan rumus:

Dari skor setiap butir pertanyaan, kemudian dikonversi ke dalam kategori sebagai berikut (Suharsimi, 2010: 192; Kothari, 2004: 85 ): $76 \%-100 \%$ = sangat baik/menarik/sesuai/efektif; $51 \%$ $75 \%$ = baik/menarik/sesuai/efektif; $26 \%-50 \%=$ kurang 
baik/menarik/sesuai/efektif; $0 \%$ -

$25 \%=$ tidak

baik/menarik/sesuai/efektif

Implementasi

a. Perangkat Lunak

OS Windows XP SP3/Windows 7

Visual Basic Application Excel

MS Office 2010

b. Instalasi

Untuk instalasi program aplikasi ini langkah-langkah yang harus dilakukan adalah:

a.a. Copy program aplikasi ke hardisk

a.b. Buka file masternya, maka akan muncul permintaan konfirmasi password. Pilih menu read only. b. Setelah program aplikasi terbuka, save as dan beri nama dengan nama user yaitu mata pelajaran, kelas, dan nama sekolah yang akan menjadi subjek analisis butir soal pilihan ganda. Langkah ini adalah langkah terakhir dalam instalasi.

Gambaran Aplikasi

a. Form Utama

Form utama pada aplikasi merupakan suatu lembar kerja dimana terdapat judul aplikasi, dan menu-menu utama statistik, mulai dari uji instrumen, uji normalitas, korelasi, regresi dan uji parametrik, dan uji non parametrik.

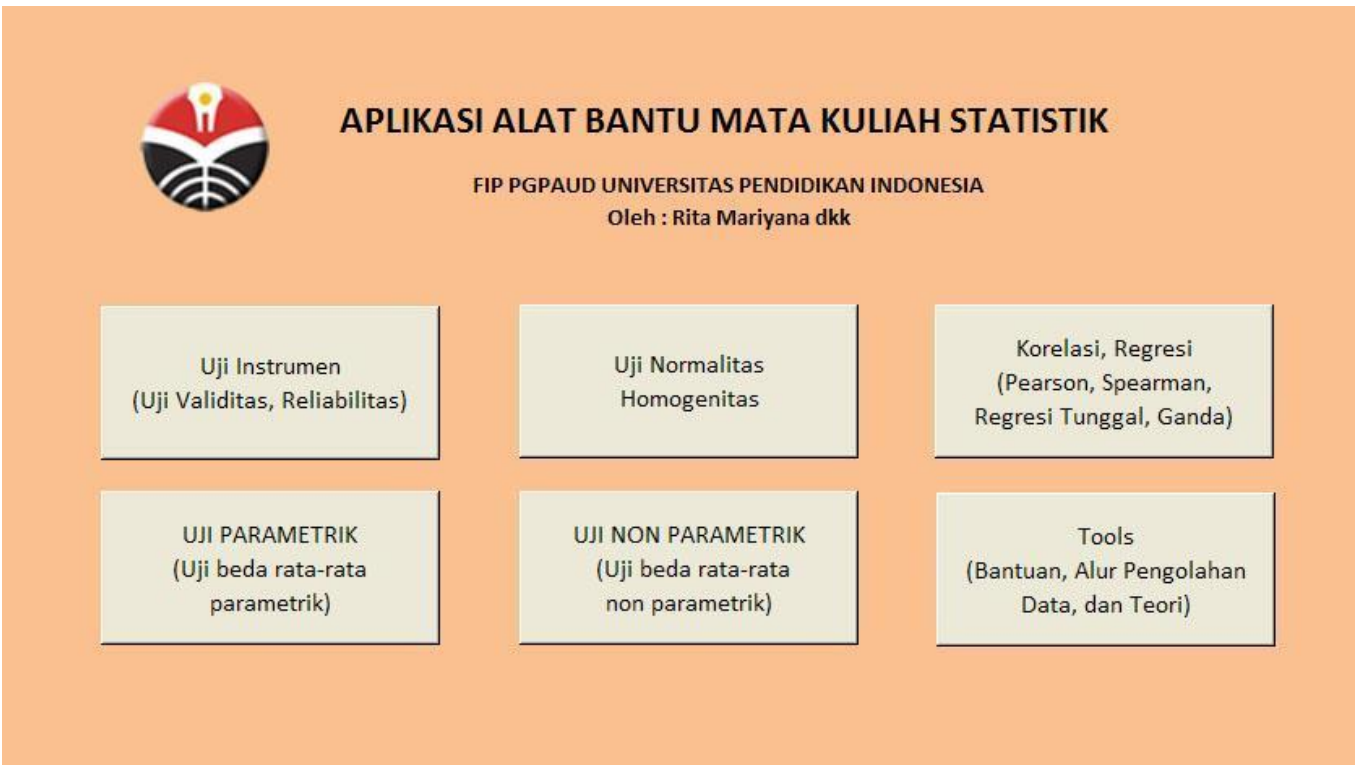

Gambar 4. Menu Utama Program Aplikasi Berbasis VBA

b. Sub Form Utama

Sub form utama merupakan lembar kerja yang menampilkan menu-menu yang lebih spesifik

dimanakita akan memilih

perhitungan apa yang akan kita 


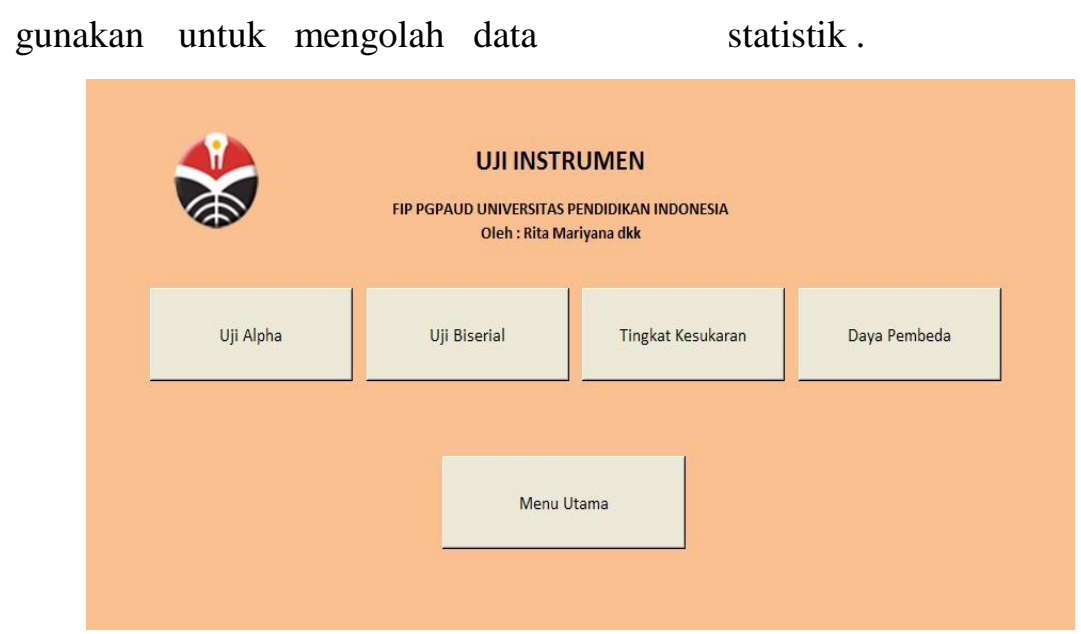

Gambar 5. Sub Menu Uji Instrumen

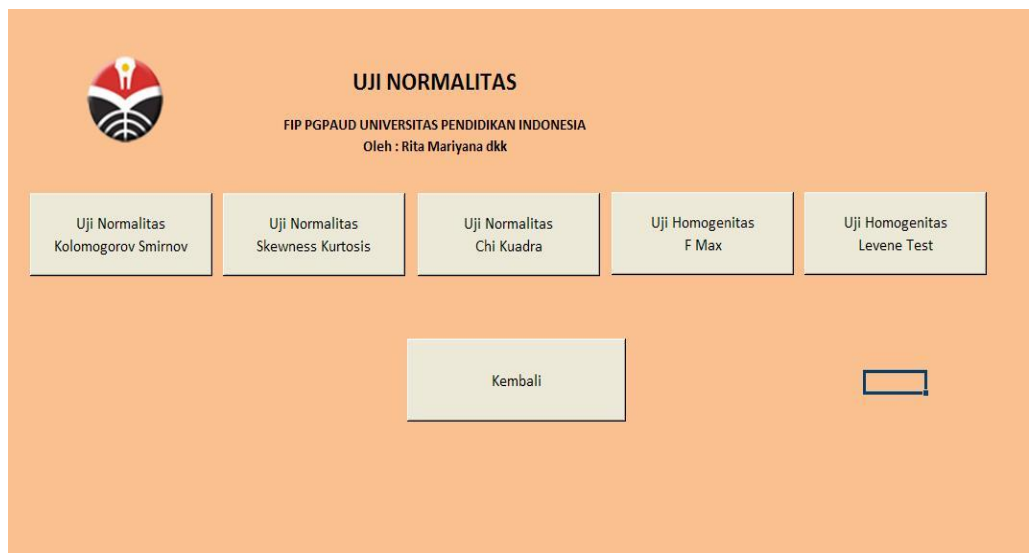

Gambar 6. Sub Menu Uji Normalitas dan Homogenitas

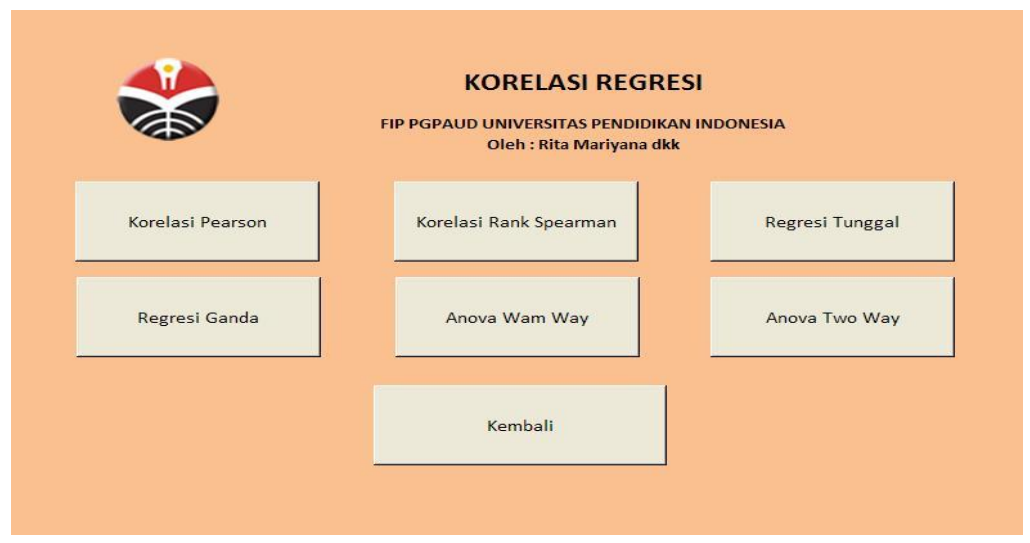

Gambar 7. Sub Menu Korelasi dan Regresi 
B. HASIL DAN PEMBAHASAN PGPAUD yang mengambil mata kuliah

Dari hasil penelitian penggunaan statistik diperoleh data hasil dari media alat bantu statistik berbasis VBA pengolahan seperti tabel berikut ini :

Excel yang dilakukan terhadap mahasiswa

Tabel 3.

Pernyataan Penggunaan alat Bantu Statistik

\begin{tabular}{|ccc|}
\hline $\begin{array}{c}\text { Butir } \\
\text { Pernyataan }\end{array}$ & Excel VBA & SPSS \\
\hline 1 & 60 & 58 \\
\hline 2 & 61 & 57 \\
\hline 3 & 59 & 51 \\
\hline 4 & 62 & 61 \\
\hline 5 & 64 & 62 \\
\hline 6 & 61 & 55 \\
\hline 7 & 58 & 57 \\
\hline 8 & 66 & 57 \\
\hline 9 & 61 & 59 \\
\hline 10 & 60 & 58 \\
\hline
\end{tabular}

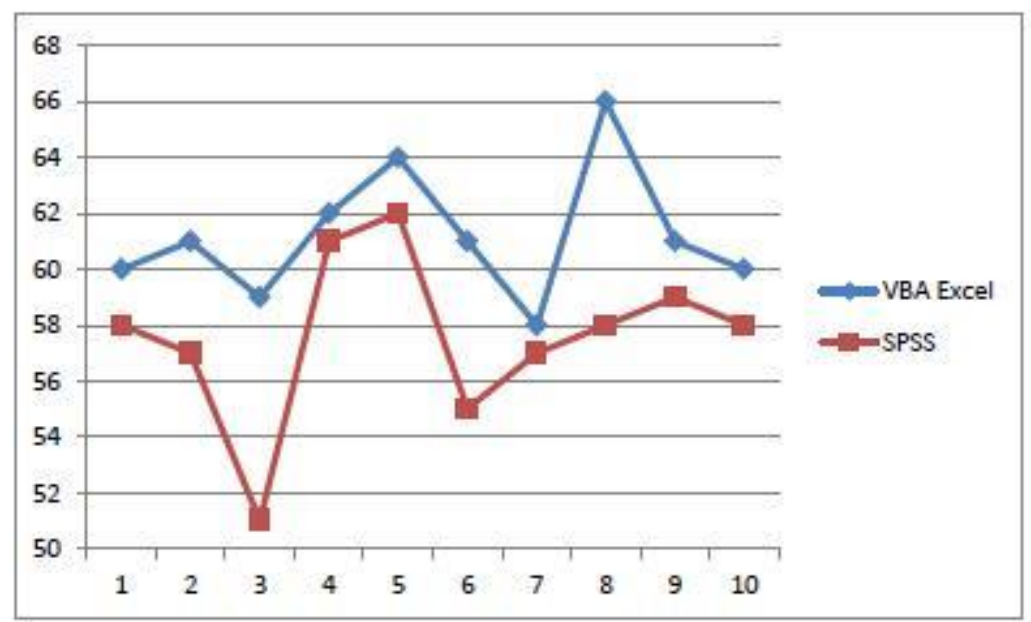

Grafik 1.

Grafik Pernyataan Penggunaan alat Bantu Statistik

Hasil ini merupakan skor untuk mata kuliah statistik. Secara statistik tiap butir pernyataan terhadap mahasiswa deskriptif data hasil pengamatan adalah PGPAUD semester 5 yang mengambil sebagai berikut :

Tabel 4.

\section{Statistik Deskriptif Alat Bantu Statistik}




\begin{tabular}{|lrr|}
\hline \multicolumn{1}{|c}{$\begin{array}{c}\text { Statistik } \\
\text { Deskriptif }\end{array}$} & $\begin{array}{l}\text { VBA } \\
\text { Excel }\end{array}$ & \multicolumn{1}{c|}{ SPSS } \\
\hline Mean & 61,2 & 57,6 \\
\hline Standard rror & 0,742369 & 0,968389 \\
\hline Median & 61 & 58 \\
\hline Mode & 61 & 58 \\
\hline Standard & & \\
Deviation & 2,347576 & 3,062316 \\
\hline Sample Variance & 5,511111 & 9,377778 \\
\hline Kurtosis & 0,871616 & 1,755436 \\
\hline Skewness & 0,924942 & $-0,86126$ \\
\hline Range & 8 & 11 \\
\hline Minimum & 58 & 51 \\
\hline Maximum & 66 & 62 \\
\hline Sum & 612 & 576 \\
\hline Count & 10 & 10 \\
\hline
\end{tabular}

Sedangkan dari pernyataan tiap Item pernyataan 1, Apakah software butir instrumen yang diberikan kepada aplikasi pengolahan data dapat bekerja mahasiswa, diperoleh data untuk tiap butir di komputer saudara? pernyataan adalah seperti berikut :

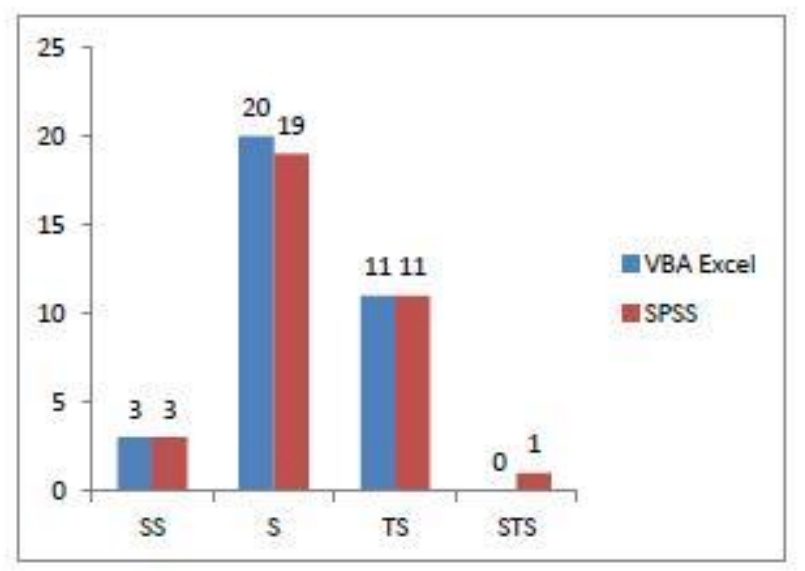

Grafik 2.

Grafik butir pernyataan 1

Dari kedua alat bantu statistik menyatakan bahwa kedua aplikasi tidak diperoleh data bahwa 22 atau lebih dari berjalan.

$50 \%$ menyatakan bahwa kedua aplikasi Item pernyataan 2, Apakah software dapat berjalan dan 12 responden mudah digunakan? 


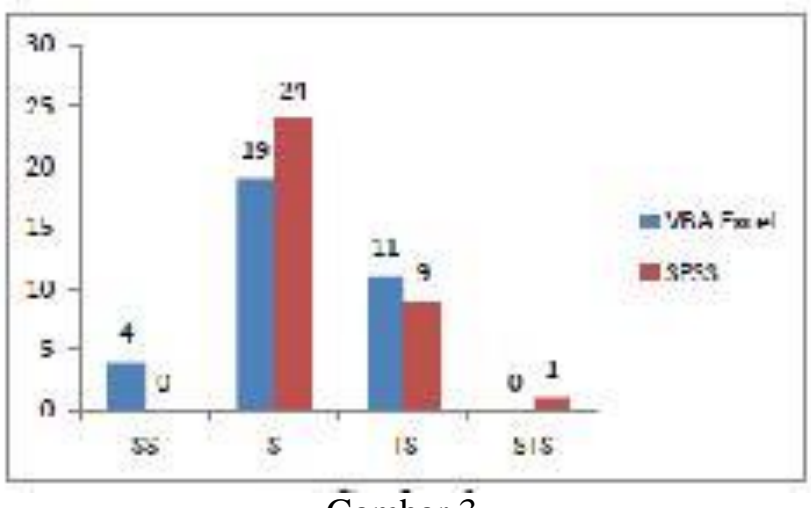

Gambar 3 .

Grafik butir pernyataan 2

Dari kedua alat bantu statistik bahwa kedua aplikasi tidak mudah diperoleh data bahwa 23 atau lebih dari digunakan. 50\% menyatakan bahwa kedua aplikasi mudah dan 11 responden menyatakan Item pernyataan 3, Apakah perintah penggunaan mudah dipahami??

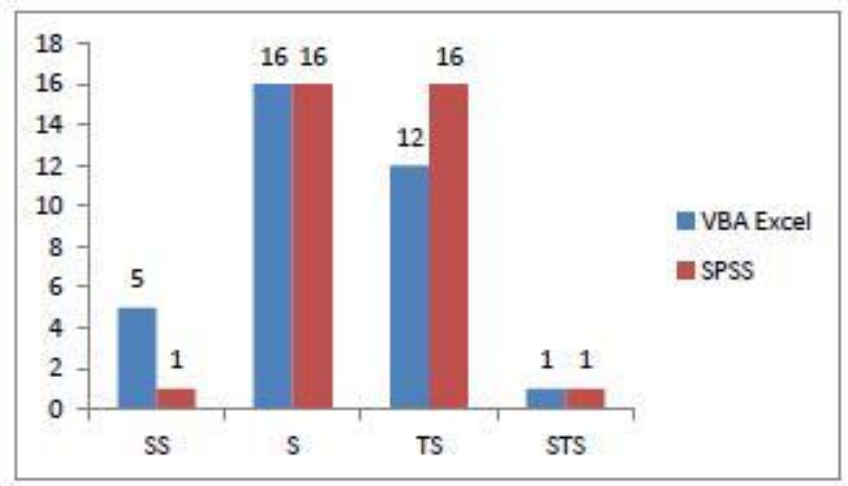

Gambar 4.

Grafik butir pernyataan 3

Dari kedua alat bantu statistik bahwa kedua aplikasi tidak mudah diperoleh data bahwa 17 atau 50\% dipahami.

menyatakan bahwa kedua aplikasi mudah

dipahami dan 17 responden menyatakan Item pernyataan 4, Apakah cara input data mudah dilakukan? 


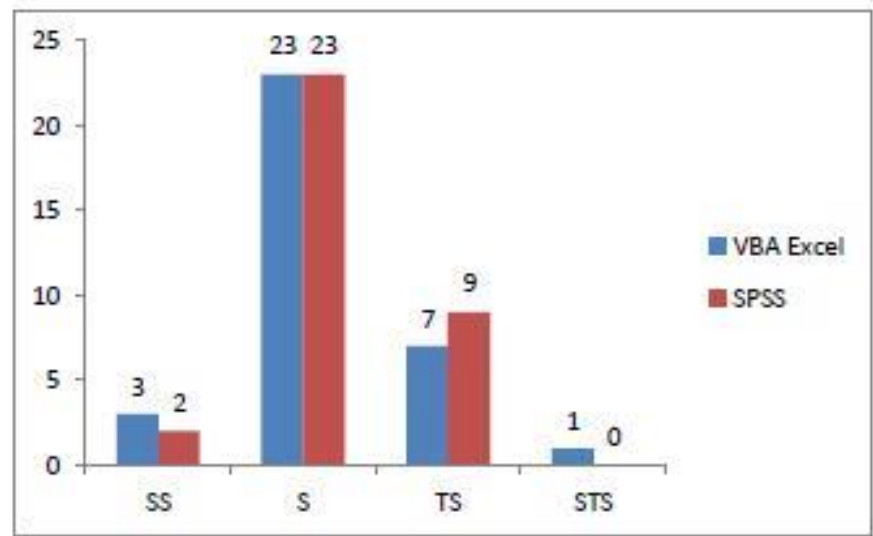

Gambar 5.

Grafik butir pernyataan 4

Dari kedua alat bantu statistik diperoleh data bahwa 25 atau $73 \%$ menyatakan bahwa kedua aplikasi mudah diinput dan 8 responden menyatakan Item pernyataan 5, Bagaimana dengan perhitungan yang dihasilkan ketika data telah di inputkan? bahwa kedua aplikasi tidak mudah diinput datanya.

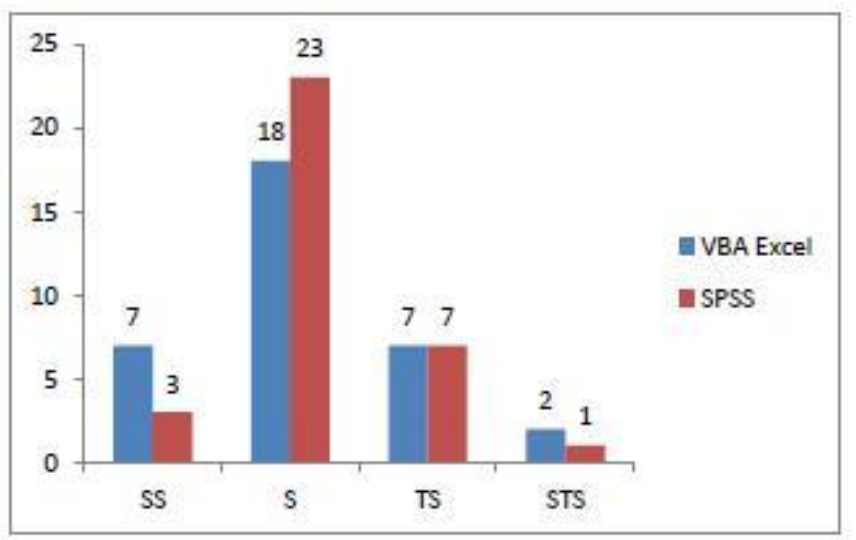

Gambar 6. Grafik butir pernyataan 5

Dari kedua alat bantu statistik sesuai dan 8 responden menyatakan bahwa diperoleh data bahwa 25 atau $73 \%$ kedua aplikasi tidak sesuai. menyatakan bahwa kedua aplikasi Item pernyataan 6, Apakah program menghasilkan perhitungan hasil yang dapat berjalan bersamaan jika aplikasi lain digunakan? 


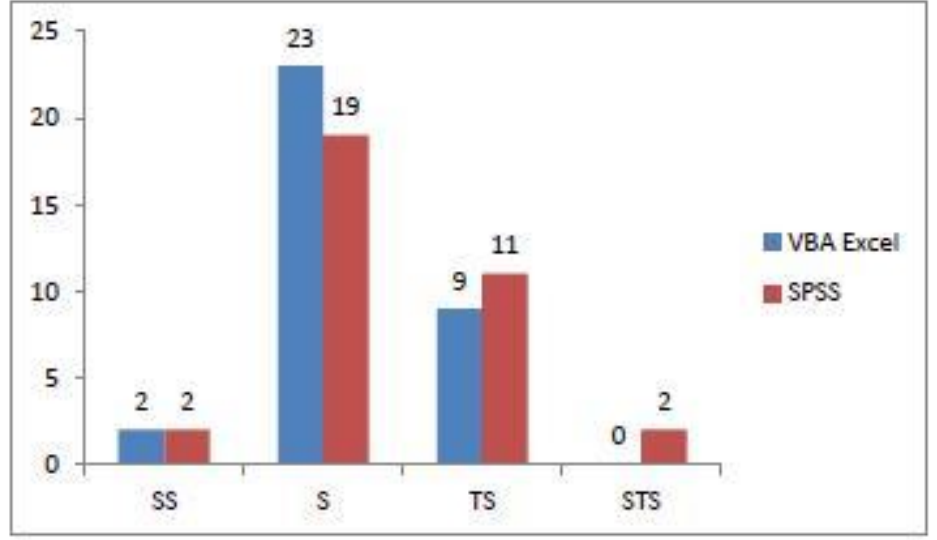

Gambar 7.

Grafik butir pernyataan 6

Dari kedua alat bantu statistik diperoleh data bahwa 21 atau $62 \%$ menyatakan bahwa kedua aplikasi dapat berjalan bersamaan dan 11 responden Item pernyataan 7, Bagaimana pemahaman anda tentang statistik dapat dibantu dengan software ini? menyatakan bahwa kedua aplikasi tidak dapat berjalan bersamaan.



Gambar 8. Grafik butir pernyataan 7

Dari kedua alat bantu statistik diperoleh data bahwa 22 atau $62 \%$ menyatakan bahwa kedua aplikasi dapat memantu pemahaman tentang statistik. dan 14 responden menyatakan bahwa kedua aplikasi tidak dapat membantu Item pernyataan 8 , Bagaimana dengan waktu yang digunakan untuk mempelajari aplikasi ini dibanding dengan mempelajari aplikasi software statistik lain? pemahaman. 




Dari kedua alat bantu statistik dipelajari sesuai dengan waktu yang diperoleh data bahwa 22 atau $62 \%$ ditentukan.

menyatakan bahwa kedua aplikasi dapat dipelajari sesuai dengan waktu yang telah Item pernyataan 9, Bagaiman dengan ditentukan dan 12 responden menyatakan bahwa kedua aplikasi tidak dapat waktu untuk mengerjakan aplikasi ini di banding dengan mengerjakan aplikasi lain?

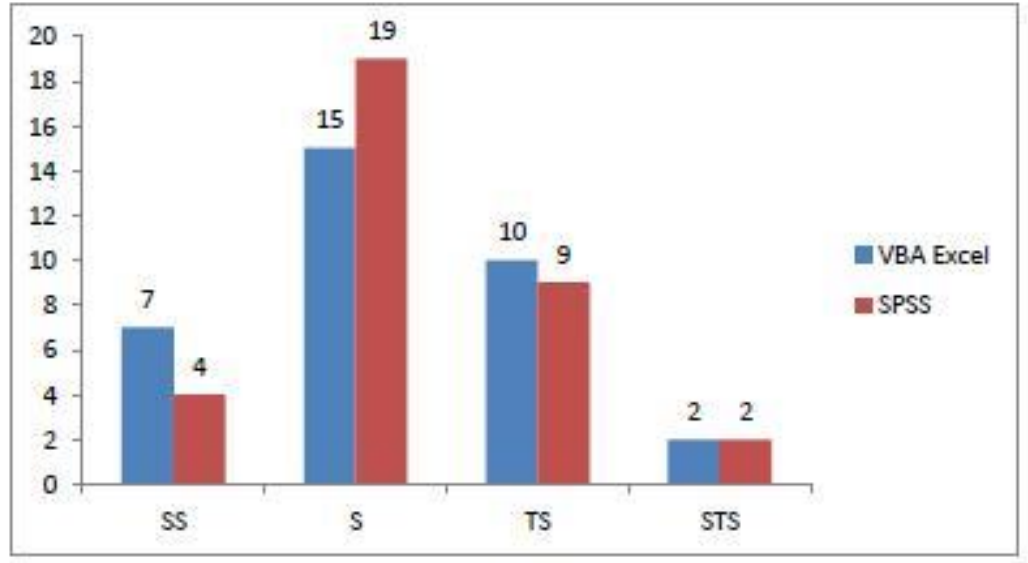

Gambar 10.

Grafik butir pernyataan 9

Dari kedua alat bantu statistik menyatakan bahwa kedua aplikasi tidak diperoleh data bahwa 22 atau $65 \%$ memenuhi waktu yang telah ditentukan menyatakan bahwa kedua aplikasi cukup untuk digunakan menyelesaikan masalah mudah digunakan untuk menyelesaikan statistik.

tugas statistik dan 12 responden

Item pernyataan 10, Bagaiaman dengan 
hasil pengolahan perhitungan apakah mudah dipahami?

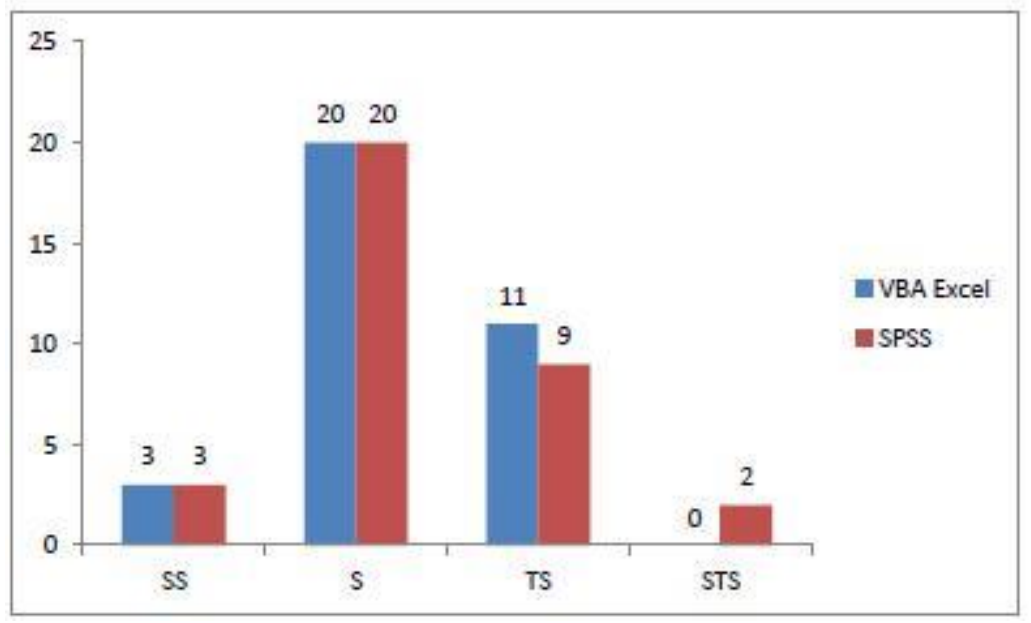

Gambar 11.

Grafik butir pernyataan 10

Dari kedua alat bantu statistik diperoleh data bahwa 23 atau $66 \%$ menyatakan bahwa kedua aplikasi cukup mudah dipahami untuk menyelesaikan tugas statistik dan 11 responden menyatakan bahwa kedua aplikasi mudah dipahami.

\section{SIMPULAN DAN SARAN}

Berdasarkan tujuan, hasil dan pembahasan penelitian mengenai pengembangan alat bantu statistik berbasis Excel VBA yang telah dinyatakan pada penjelasan penelitian ini maka diperoleh kesimpulan sebagai berikut :

a. Media pembelajaran alat bantu statistik berbasis VBA Excel menambah alternatif media dalam proses pembelajaran, dimana media dapat memberi kemudahan dalam penyelenggaraan perkuliahan. Media pembelajaran ini dapat menjadi alat bantu bagi dosen, pengelola, pengembang, lembaga pendidikan dan peneliti selanjutnya yang ingin mengkaji dan mengembangkan secara lebih mendalam mengenai alat bantu statistik berbasis VBA Excel.

b. Sebagai pertimbangan dan alternatif bagi dosen dalam pemilihan media pembelajaran, sehingga dosen mampu membuar rancangan dan inovasi baru yang mampu mengeksploitasi daya nalar mahasiswa dengan memperbanyak media ajar mandiri.

c. Media pembelajaran alat bantu statistik berbasis VBA Excel menambah alternatif media dalam proses pembelajaran, dimana media dapat memberi kemudahan dalam penyelenggaraan perkuliahan. Media pembelajaran ini dapat menjadi alat 
bantu bagi dosen, pengelola, pengembang, lembaga pendidikan dan peneliti selanjutnya yang ingin mengkaji dan mengembangkan secara lebih mendalam mengenai alat bantu statistik berbasis VBA Excel.

d. Sebagai pertimbangan dan alternatif bagi dosen dalam pemilihan media pembelajaran, sehingga dosen mampu membuat rancangan dan inovasi baru yang mampu mengeksploitasi daya nalar mahasiswa dengan memperbanyak media ajar mandiri.

Berdasarkan hasil penelitian yang telah diuraikan pada kesimpulan hasil penelitian, berikut ini diajukan beberapa saran, yaitu:

1. Mengingat penelitian pengembangan media ajar alat bantu statistik berbasis VBA ini hanya dilakukan sampai uji coba lapangan terbatas untuk melihat tanggapan mahasiswa terhadap produk alat bantu statistik berbasis VBA, sehingga dibutuhkan penelitian selanjutnya untuk menguji keefektivan media yang dikembangkan. Sehingga media pembelajaran yang dikembangkan dapat lebih sempurna.

2. Dari beberapa saran-saran mahasiswa yang menggunakan aplikasi VBA Excel ini, masih ada kekurangan dalam penggunaannya, sehingga kedepannya kompatibilitas aplikasi terhadap sistem operasi yang ada dapat lebih ditingkatkan, ini muncul dari beberapa peserta yang tidak langsung berhasil dalam menjalankan aplikasi alat bantu olahdata statistik berbasis VBA.

3. Untuk penelitian selanjutnya, sebagai produk lanjutan penelitian ini adalah pengembangan software aplikasi add in excel sehingga kompatibilitas software lebih baik

4. Untuk para tim dosen pengampu mata kuliah statistik di Universitas Pendidikan Indonesia khususnya, diharapkan dapat mengaplikasikan software aplikasi VBA Excel ini dalam proses pembelajaran mata kuliah statistik

Pengembangan software aplikasi alat bantu olahdata statistik berbasis vba serta media pembelajaran branching linier dibuat untuk membantu proses belajar mengajar statistik dengan mempertimbangkan kemudahan dan kesederhanaan proses sehingga peserta didik dapat dengan cepat melakukan implementasi. Pembuatan aplikasi dirancang dengan menerima berbagai masukan dan ide yang dapat membantu peserta didik khususnya mahasiswa PAUD untuk lebih mudah dalam memahami statistik.

Aplikasi ini dikembangkan beberapa tujuan yang ingin dicapai seperti efektifitas pembelajaran, efesiensi pembelajaran, pembelajaran yang inovatif, memotivasi 
peserta didik dan pembelajaran mandiri dapat dilakukan. Untuk mampu lebih optimal, materi ajar dapat disesuaikan dengan kemampuan peserta didik.

\section{DAFTAR PUSTAKA}

DeMarco, John. (2008). Pro Excel 2007 VBA: Learn to build highperformance applications in Excel 2007 using VBA. Berkeley:Apress.

Jelen, Bill and Dwayne K. Dowell. (2007). Excel forAuditors. Uniontown: Holy Macro! Books.

Jelen, Bill. (2005). Learn Excel from $M r$, Excel. Uniontown: Holy Macro! Books.

Jelen, Bill. (2008). 377 Excel Mysteries Solved. Uniontown: Holy Macro! Books.

Jelen, Bill. (2009). Excel Gurus Gone Wild. Uniontown: Holy Macro! Books.

Nana Sudjana, Ahmad Riva'I (1989). Teknologi Pengajaran. Bandung: Sinar Baru dan Lembaga Penelitian IKIP Bandung.

Singgih Santoso (2002). Mengolah Data Statistik Secara Proposional. Jakarta : Elekmedia Komputindo

Sudjana (2005). Metode Statistika. Bandung : Tarsito

Suharsimi (1998). Prosedur Penelitian Suatu Pendekatan Praktek. Jakarta : Rineka Cipta

Walkenbach, John. (2010). Excel 2010 Power Programming with VBA. Indianapolis: Wiley Publishing Inc..
Walkenbach, John. (2010). Microsoft Excel 2010 Formulas. Indianapolis: Wiley Publishing Inc..

Walkenbach,John. (2004). Excel VBA Programming for Dummies. Indianapolis: Wiley Publishing Inc. 